\title{
NON INNER-CITY GENTRIFICATION IN ISRAEL
}

\author{
Amiram Gonen \\ Department of Geography, the Hebrew University of Jerusalem, Israel \\ e-mail:msgonena@huji.ac.il
}

\begin{abstract}
In the recent two decades, as result of growing preference among the Jewish middle class for detached residence, many suburbs and villages were subject to gentrification. Especially prone to gentrification, were housing estates built in the 1950s at low densities. It was, then, the increasing suburbanization middle-class households that brought about the gentrification of these neighborhoods. A similar process took place in immigrant towns and villages on the periphery of metropolitan regions.
\end{abstract}

Key words: Neighborhood gentrification, inner city, middle class, low-income neighborhoods, outlying public housing projects, place gentrification.

Gentrification of urban neighborhoods is often associated in the literature with the inner city. Indeed, the penetration and settling of middle-class households in lower-social class neighborhoods of the inner city achieved sizeable proportions in North American, Australian and some West European cities during the 1970s and 1980s. As a result much the debate that has developed among social scientists was whether gentrification does indeed pose a substantial challenge to the established urban residential structure of Western cities (Badcock, 1989, 1991; Berry, 1985; Bourassa, 1993; Bourne, 1989, 1993; Bridge, 1994; Hamnett, 1984, 1991, 1992; Ley, 1986, 1993; Smith, 1979, 1987, 1992). The main theoretical question raised in this debate is whether the renewed interest of the middle class in the inner city will indeed bring about a reshuffling in the role of the inner city as a predominantly low-income residential component in many Western cities. The debate also centers on the driving force behind recent gentrification of neighborhoods in the inner city: is it economic or cultural in character? Is gentrification of the inner-urban areas a process generated by the attraction of the rent gap in the inner city or is it the result of change from a suburban to an urban lifestyle? A compromise between the two approaches has been suggested with regard to this complex process (Ley, 1991; Smith, 1992). However, even this debate on the underlying causes of gentrification is based primarily in the view that gentrification is largely a process which takes place in the inner city and its immediate environment. 
However, this preoccupation with the inner city as the locus of gentrification overlooks the theoretical possibility that gentrification could take place outside the inner city in cities where low-income neighborhoods exist in outer urban areas and even in the suburbs. Theoretically, wherever a demand develops among middle-income households for particular low-income neighborhoods, a gentrification process might be set in motion, even if these neighborhoods are located outside the perimeter of the inner city. Indeed, low-income neighborhoods are widely common in the periphery of many cities, in countries where suburbanization of the middle classes has not been the most prevalent residential process. When such a move of middle-income households to a suburban location does indeed take place in this kind of cities, it is likely to be channeled not only to newly built middle-class neighborhoods, as is most often the case, but also to some low-class neighborhoods that have some locational and physical attributes attractive to the settling of such households.

This is what is happening in Israeli cities and metropolitan regions in recent decades. As a result, the recent process of neighborhood gentrification in Israeli cities is more spatially widespread and thus more diverse than the one depicted in the literature dealing with this process in Western cities. The reason for this difference is embedded in a different overall spatial residential structure that has characterized Israeli cities in prior decades: middle-class neighborhoods clustering mostly in the inner areas while low-income neighborhoods spreading in the urban periphery. For many decades, the middle-class Jewish households preferred the inner city as a place of residence. These households were, and still are, prominent in the inner-urban neighborhoods. They cherished access to the urban amenities and services in addition to proximity to place of work. They followed the prevalent preferences of middle-class population in their main countries of origin: Continental and Mediterranean Europe as well as the Middle East and North Africa. Even with the recent trend toward increased suburbanization, kindled by the growing preference for spatial residential privacy - a detached house and an attached garden - many of the inner-city neighborhoods are still inhabited by middle-class population. Such new inner-city neighborhoods have been built in recent decades, and still are, resulting in the broadening of the spatial extent of the middle-class sector of the inner city.

Gentrification of inner-city neighborhoods has taken place in a limited scope (Gonen, 1995). Such inner-city gentrification does not constitute a significant departure from the long-standing preference among the Israeli middle class for inner city living. However, it does represent a departure from the long-time tendency among the Jewish middle class in Israel of shying away from old dwellings and old neighborhoods, marked by obsolescence and physical deterioration and by neighbors of lower social class. Indeed, this bias against old urban neighborhoods has diminished since the early 1970s among a small part of the urban Jewish middle class. A taste for the old, not only in housing but also in furniture and other artifacts, has been increasingly evident among middle-class households. This kind of change in residential preference, and not a suburb-to-city movement, so important in the emergence of inner-city neighborhood gentrification in Western cities, underlies the limited gentrification of some inner-city neighborhoods in the larger cities of Israel, particularly in Jerusalem and Tel Aviv (Cohen, 1985). Nevertheless, altogether gentrification of innerurban neighborhoods is quite limited in spatial scope in Israel. There are not too many 
lower-class neighborhoods in the inner part of Israeli cities. There was, therefore, not enough room for a sizable neighborhood gentrification of inner city, as has been the case in some Western cities.

However, this does not mean that neighborhood gentrification did not take place in Israeli cities in parts other than those of the inner city. Middle class households, willing to take upon themselves the upgrading of an old house, did not restrict themselves to innercity neighborhoods. They have soon discovered that in addition to the few lower-class neighborhoods in the inner city, there was a large supply of semi-detached houses with a substantial potential for upgrading in the outer-urban areas. One can find such houses in many of the housing projects, set up by public agencies in the early 1950s on the periphery of existing cities and towns. These housing projects were built in order to quickly and cheaply supply shelter to the many immigrants arriving in the country in those years as well as to provide adequate housing to working class households living in the country for quite some time in crowded conditions in the inner urban areas (Gonen, 1975). In the 1950s, the mode of a semi-detached house (known in Israel as 'two-family house) was popular among public housing agencies, assigned to provide housing for the mass immigration. The reasons for opting for the detached but mostly for the semi-detached mode of housing construction is less embedded in reasons of expediency and economic efficiency and more in the prevailing societal concepts of those years. The leadership of the then newly established housing agencies came largely from among the labor movement, then staffing most of the governmental positions in the country. The development of rural settlement ranked high in the labor movement, for years preoccupied in establishing agricultural settlements around British Palestine. Settling and tilling the land was an important concept in the Zionist movement at large but a prime one in the labor movement. After the establishment of the State of Israel, this labor-oriented leadership was engaged in setting up hundreds of agricultural settlements, many of them for the new immigrants (Gonen, 1998). However, it was obvious then that the proportion of immigrants to be allocated to agricultural settlements is limited and that a large part of them have to be directed toward cities and towns, old and new. The adoption of a semi-agricultural pattern of settlement for the early phase of urban housing construction can be interpreted as an extension of the 'ruralist' ideology of the labor movement into an urban setting. In their physical layout, the new urban housing projects were indeed quite reminiscent of that of (cooperative agricultural villages -moshavim - built at the same time and settled by the same kind of immigrants. The main difference between moshavim and the urban housing projects built around Israeli towns was in the prevalent mode of housing. The detached house was the only type of housing built in moshavim while in the urban housing projects the semi-detached house was the prevalent one. The plot around the semi-detached house, though smaller than the one found in the agricultural settlements, was large enough to allow the urban settlers to practice what the planners of these housing projects envisaged as 'auxiliary' agriculture. The underlying idea was that the plot around the house would enable residents to secure some income from growing vegetables and fruit trees and perhaps raise some goats or even a cow or two. The shortage of food in the country was quite severe in the early 1950s and so was the high level of unemployment. The plot around the house was regarded as a safety net the state can provide to the residents 
of the housing projects built all over the country on the periphery of cities and towns. There was an additional motive to this low-density housing construction for a low-income population. The leading planners in the 1950s came from among the rural sector of the Jewish population. The same politicians and professionals that have conducted the settling of recent immigrants in agricultural villages have also designed the urban housing projects built in the early 1950s. They tried to connect immigrants settling in an urban milieu with the some token agricultural existence, which in those days still played an important ideological role in Israel (Gonen, 1975).

The bulk of the semi-detached houses built in the public housing projects lie on the periphery of existing cities and towns. This spatial pattern construction of the urban periphery can be explained by the availability there of large tracts of publicly owned land the lack of already established urban planning. These conditions enabled a quick and less expensive construction process, so badly needed in face of the acute housing shortage of the 1950s (Gonen, 1995). The fact that the housing sector was very large in those years and the pattern of governance very centralized led to the prevalence of semi-detached house in public housing projects built during much of the 1950s.

However, contrary to the vision of the planners the residents did not use the plots around the semi-detached houses for their intended use as auxiliary farms. They were hardpressed to find an urban job and had very little time to take care of a vegetable garden, let alone a garden of shrubs and flowers. Whatever surplus income they had they invested in improving their housing conditions. Residents have gradually added extensions to the original small houses, often with little regard for quality of materials and design, since many of the residents had very little money to spend. The ample land around the houses enabled these extensions. Allowing for the growth of one's dwelling unit on the housing projects soon became the major function of the large plot, originally designated to be used for 'auxiliary' agriculture. The original semi-detached houses built by the public housing agencies in the 1950s were very small even though plots around them were relatively large. The size of a standard dwelling unit built in the early 1950s in public housing projects was between 30 and 45 square meters on a plot more than ten times as large. On one hand, public housing agencies were interested in the early 1950s in providing a bare minimum of shelter for a maximum number of the impoverished immigrants with the limited resources available then for construction purposes. On the other hand, the agencies perceived land as being in ample supply in those years. The combination of limited resources for housing construction and the perception of a limitless supply of land has resulted in this predominant pattern of low-density housing for low-income households on the in the urban as well as the national periphery. It is this kind of combination between low density and low socioeconomic status, which several decades later has attracted middle class households to consider taking advantage of the large plots and the low real estate values

The initial composition of residents in these outlying housing projects was a major factor underlying the low real estate values in these outlying housing projects. Up to the 1980 many of these housing projects have experienced outward migration of their more upwardly mobile residents, opting to inner neighborhoods of a higher socioeconomic status (Gonen and Hasson, 1974). Residents moved to inner urban areas or to newer housing pro- 
jects built in the 1960s and onwards, where the size of the dwelling units was larger, construction quality better and the socioeconomic status of neighbors higher. As a result, these housing projects of the 1950s, though of a rather low residential density, have persisted as to residential areas of low socioeconomic status, where real estate values were relatively low, in comparison to other parts of town.

The process of gentrification reached some of these outer housing projects marked by semi-detached houses in the 1980s and 1990s. It is an ongoing process in the 2000s. Easy access to the city center and a romantic urban architecture are not the prime motive in these outlying housing projects, as is the case in the gentrification of inner-city neighborhoods. The driving process causing the gentrification of some of the low-density housing projects is the growing search for detached or semi-detached residence among middle class households in Israel. It is the increasing popularity of the "private house and garden" that has increasingly sent middle class households to look for a "villa" (a detached house) or a "cottage" (a semi-detached house). In recent decades, this growing preference for spatial privacy of residence led many Israeli middle-class households to the suburbs, at the expense of easy access to jobs and services. Israel has indeed experienced recently a massive process of suburbanization. This process has taken many forms and in a variety of places. The more fashionable and more expensive places are the new neighborhoods or settlements, consisting mainly of detached and semi-detached houses built around Israeli cities. This pattern followed the one that has taken place in Western cities undergoing a massive suburbanization of the middle-class population The 'social insularity' of the middle class was an important added social value in these places. The change in governmental land policy taking place in recent decades that has increasingly allowed conversion from agricultural to residential land use on the periphery of cities played an important role in recent years in allowing the construction of new suburban neighborhoods and settlements for middle class occupancy. So did the policy of encouraging the establishment of new Jewish settlements in areas of geopolitical considerations.

In addition to this middle-class move to new suburban neighborhoods and settlements, some middle-class households found residence in existing housing projects built on the outskirts of towns in the 1950s. In these housing projects semi-detached houses standing on relatively large plots could be found in huge numbers and at reasonable prices. However, in spite of the large potential for gentrification in these former housing projects, the process has been rather slow. The social milieu was not very attractive to the bulk of middle class population. Moving into such a neighborhood meant sharing space with neighbors of a different social status and cultural lifestyle. It meant sharing with them schools and other pubic services. The bulk of the middle-class population interested in the new residential lifestyle was not rushing to such neighborhoods. As was often the case in the gentrification of inner-city neighborhoods, the first middle-class households to penetrate into these former housing projects were of a more pioneering character. They either were less sensitive to the social milieu or were willing to take the social risk in view of their limited financial resources. There were also those who identified the 'rent gap' in advance and were therefore ready to take for a while the temporary social burden, in the hope that it will eventually result in a substantial rise in the value of their property, which was in did the case as more middle- 
class households joined the process. A pioneering spirit was necessary for overcoming the intensive effort involved in turning a house that has been poorly extended, if at all, by its former residents of very modest means and taste, into a trendy suburban 'cottage'.

The presence of a large number of such housing projects in the periphery in most Israeli cities has substantially shaped the spatial pattern of neighborhood gentrification in these cities. Together with the old inner-urban neighborhoods, adjacent to the city center, they rendered neighborhood gentrification a spatially widespread process, not one focusing around the inner city only, as is often the case in Western cities. The spread of gentrification over the urban space follows the widespread nature of the geographical distribution of the lower-class population in Israeli cities. Jerusalem, in particular, serves as a clear example of such spatial diversity of gentrification. Gentrification took place in Jerusalem both in the old inner-city neighborhoods adjacent to the city center as well as in some of the housing projects built in the 1950s in the southwestern periphery (Gonen, 2002).

The spread gentrification in Israel as a result of suburbanization goes far beyond the limits of cities. In their quest for detached or semi-detached residence, middle-class households have also reached suburban towns that were built in the 1950s for the huge wave of immigrants coming into the country. These towns were part of a series of new immigrant towns developed in the early decades of statehood as part of a policy of population dispersal. The policy affected mainly low-income immigrants depended on publicly subsidized housing. These towns have undergone a residualization process, as did many of the outlying housing projects discussed above. However, with increased suburbanization, a growing number of middle-class households have taken up residence in some of these towns. Noted examples are Mevasseret Ziyyon west of Jerusalem, Yavne and Rosh Ha'ayin on the margins of the Tel Aviv metropolitan region and Yoqneam and Migdal Ha'emeq near Haifa. But in this kind of suburban towns the settling of the new residents has been largely in new neighborhoods built since the late 1970s adjacent to those built for the immigrants in the 1950 s and 1960s. This process was part of a state policy to harness the suburbanizing middle class into upgrading the socioeconomic level of these towns (Gonen, 1998). For this purpose, state agencies were involved in providing land, planning and subsidies for the development of new 'villa' and 'cottage' neighborhoods in these towns. However, the new neighborhoods were built apart from the existing neighborhoods, in order to accommodate to the social and cultural preferences of the suburbanizing middle-class households. What has emerged is not necessarily gentrification of an existing housing stock but rather gentrification of a locality. The social composition of the population of the locality was upgraded, and so were the social and the commercial services. A somewhat similar development took place in the housing projects on the periphery of cities. Immediately adjacent land tracts were built as new streets of detached residence to serve the demand on the part of middleclass households, thus affecting the social composition of these residential areas. All these development, add to the need to perhaps redefine gentrification as a process affecting places, whether neighborhoods and towns, both in terms of upgrading an existing housing stock and the construction of a new one. The need for this redefinition of gentrification stems from its widespread nature as a result of being associated with suburbanization of the middle class and not only with its reurbanization, as is the case some Western cities. 


\section{References}

Badcock, B.A., 1989: An Australian View of the Rent Gap Hypothesis, Annals of the American Association of Geographers, 79 (1), 125-145.

Berry, B.J.L., 1985: Islands of Renewal in Seas of Decay, in Peterson, P. (ed.), The New Urban Reality, The Brookings Institution, Washington, 69-96.

Bourassa, S.C., 1993: The Rent Gap Debunked, Urban Studies, 30 (10), 1731-1744.

Bourne, L.S., 1989: Are New Urban Forms Emerging? Empirical Test for Canadian Urban Areas. The Canadian Geographer, 33, 312-328.

Bourne, L.S., 1993: The Myth and Reality of Gentrification: A Commentary on Emerging Urban Forms. Urban Studies, 30 (1), 183-189.

Bridge, G., 1994: Gentrification, Class and Residence: A Reappraisal, Environment and Planning D: Society and Space, 12, 31-51.

Cohen, G., 1985: The Settling of Households of Upper Socio-Economic Status in Neighbourhoods of Lower Social Status in Jerusalem, Unpublished PhD Dissertation in Geography, The Hebrew University of Jerusalem, Jerusalem (Hebrew).

Gonen, A., 1975: Locational and Ecological Aspects of Urban Public-Sector Housing: The Israeli Case', in G. Gappert and H. Rose (eds.), The Social Economy of Cities (Urban Affairs Annual Reviews Vol. 9), Sage Publications, Beverly Hills/London, 275-295.

Gonen, A., 1995: Between City and Suburb: Urban Residential Patterns and Processes, Avebury, Aldershot.

Gonen, A., 1998: Changing Policies for the Peopling Israel's Frontier, in O. Yiftachel and A. Meir (eds.), Ethnic Frontiers in Israel, Boulder CO: Westview Press, 141-210.

Gonen, A., 2002: Widespread and Diverse Neighborhood Gentrification in Jerusalem, Political Geography 21 (5), 727-737.

Gonen, A. and Hasson, S., A Centripetal Pattern of Intra-Urban Mobility in Israel MediumSized Towns," Geogragiska Annaler, Nol. 56B, No. 3, 1974, 144-151.

Hamnett, C., 1984: Gentrification and Residential Location Theory: A Review and Assessment, in D. Herbert and R.I Johnston, (eds.) Geography and the Urban Environment, John Wiley and Sons, Chichester, 283-319

Hamnett, C., 1991: The Blind Man and the Elephant: The Explanation of Gentrification, Transactions, Institute of British Geographers, 81, 181-209.

Hamnett, C., 1992: Gentrifiers or Lemmings? A Response to Neil Smith, Transactions, Institute of British Geographers, New Series, 17, 116-119. New York

Laska, S.B. and Spain, D. (eds.) 1980: Back to the City, Pergamon, Elmsford, N.Y.

Ley, D., 1986: Alternative Explanations for Inner City Gentrification: A Canadian Assessment, Annals of the Association of American Geographers, 76 (4), 521-535.

Ley, D., 1988: Social Upgrading in Six Canadian Inner Cities, The Canadian Geographer, $32,31-45$.

Ley, D., 1991: 'The Inner City', in T.E Bunting. and Filion, P. (eds.) Canadian Cities in Transition, Oxford University Press, Toronto, 313-348.

Ley, D., 1993: Past Elite and Present Gentry: Neighbourhoods of Privilege in the Inner City, in Bourne, L. and Ley, D. (eds.) The Changing Social Geography of Canadian Cities, McGill-Queens University Press, Montreal, pp. 214-233. 
Ley, D., 1994: Gentrification and the Politics of the New Middle-class, Environment and Planning D: Society and Space, 12, 53-74.

Smith, N., 1979: Toward a Theory of Gentrification: A Back to the City Movement by Capital, not People, Journal of the American Planning Association, 45, pp. 538-548.

Smith, N., 1987: Of Yuppies and Housing: Gentrification, Restructuring and the Urban Dream, Environment and Planning D: Society and Space, 5, pp. 151-172.

Smith, N., 1992: Blind Man's Buff, or Hamnett's Philosophical Individualism in Search of Gentrification, Transactions, Institute of British Geographers, New Series, 17, 108-119.

Smith, N. and Williams, P. (eds.), 1986: Gentrification of the City, Allen and Unwin, Boston.

Warde, A., 1991: Gentrification as Consumption: Issues of Class and Gender, Environment and Planning D: Society and Space, 9, pp. 223-232. 